\title{
The therapeutic approach as an important intervention in the implementation of the program Project learning for young adults (PUM-O)
}

\author{
Nataša Demšar Pečak \\ The Family Study and Research Centre, Gorazdova 2, 1000 Ljubljana, Slovenia \\ natasa.dp1@gmail.com
}

\begin{abstract}
This article presents the program Project Learning for Young Adults" (PUM-O), the main purpose of which is to develop the potential of vulnerable young adults for successful integration into education, the development of professional identity and successful integration into the labour market and successful social integration. These young adults have different reasons for abandoning education and lack of work experience therefore; they have difficulties to find employment. Due to the impaired mental health of individuals, the program is the only way out of the current plight and the only possibility of re-control of their lives, as well as successful confrontation with various problems. Because the program is not a therapeutic one and the mentors generally are not therapists, it is extremely important that the mentors in the program, unless they are also therapists, include other relational therapists. With the majority of the participants, their relational needs are not satisfied, so this deficit is reflects in loneliness, dissatisfaction, fear, despair, selfinjuring, aimless vegetating, violence, depression and various addictions. Many participants from mentors-therapists for the first time experience safe, compassionate and respectful relations, as well as a sense of acceptance and value, which results in a change of symptomatic deeprooted patterns of interpersonal interaction. Program participants also experienced a therapeutic approach of mentors-therapists as an important intervention for getting new positive experience on which they acquire functional activity and better contact with themselves. Key words: mental health, young adults, therapeutic approach, intervention, interpersonal relations
\end{abstract}


publicly valid program of non-formal adult education program "Project learning for young adults (PUM)" in Slovenia was created in the

nineties. The program PUM was one of the first publicly approved educational programs for adults, prepared in accordance with the guidelines of curricular reform of education for adults. The purpose of creating such a program was mainly reducing social exclusion of the most vulnerable groups of young NEETS (youngsters not employed, educated or trained). Since its inception, the program has developed, supplemented and amended. There have been completed also the evaluation studies in 2002 (Istenič Starčič et al., 2002), and 2010 (Možina et al., 2010) which have demonstrated both the quality as well as the shortcomings of the program and the new needs of young people, especially the new opportunities for developing and completing the program.

\section{The purpose and goals of the program PUM-O}

Based on the experience of many years of the program PUM and based on the new social circumstances a demand for a new program "Project learning for young adults (PUM-O)" has appeared. It was built at the initiative of the Ministry of Labour, Family, Social Affairs and Equal Opportunities (MDDSZ) and on the basis of the Operational Program for the Implementation of the European Cohesion Policy in the period 2014-2020. The program is aimed at vulnerable groups of young adults from 15 to 26 years who have dropped out of school or have not acquired the proper education that would allow them to get the appropriate employment.

The PUM-O is formed as an upgrade of previously mentioned PUM program, of which it differs considerably. Compared with the PUM program, whose main objective was to enable young people to gain experience and skills to continue successfully their education, the main objective of the new program PUM-O is convergence and entry of participants into the labour market. Extending the target group of the program is also reflected in the fact that the PUM-O compared with PUM also aims at students who are involved in regular education, but threatened by the risk of dropout. Therefore, we can conclude that the substantial modification of the program PUM is integration of participants into the labour market. The program is directed markedly to process and provides in-depth cooperation between different resources, allowing participants to fulfil their personal career plan (Žalec et al., 2015).

As stated by the different authors (Možina et al., 2010), it is a fundamental objective of the program to help young people to gain experience and knowledge that would enable them to be successful in further education or the chosen career path. It is very important for them to obtain functional knowledge that develops general education: wide horizons and flexibility of thinking, getting a positive learning experience, clearly articulated career aspirations and developing skills in critical and problem-oriented thinking. This program encourages young people in three areas of activity, namely the spread of general education, the formation of professional identity and socio-cultural activities. 


\section{The importance of the therapeutic approach}

It is very important for each participant to identify and define his or her fundamental problems, which may show us unconscious and compulsive intergenerational transmission or intergenerational transmission of behaviour patterns, feelings and beliefs. Intergenerational transmission might thus be defined as instances of social transmission between members of different generations. Martin-Matthews and Kobayashi (2009) state that we can also describe intergenerational transmission as behaviour or tendencies of one generation passing onto the next generation. Intergenerational transmission is one dimension of the larger concept of intergenerational relations. The term intergenerational relation describes a wide range of patterns of interaction among individuals of different generations of the family: for example, among those in older generations, such as parents and grandparents and those in younger generations, such as children and grandchildren. What is transmitted may be intangible and may include beliefs, norms, values, attitudes, and behaviours specific to that family, or may reflect socio-cultural, religious, and ethnically relevant practices and beliefs (Chen and Kaplan, 2001; Capaldi, Pears, Patterson and Owen, 2003; Martin-Matthews and Kobayashi, 2009).

The theory states that parents of one generation have a tendency to repeat the parenting model which their parents applied on them (Serbin and Karp, 2003). Family researchers have also studied the intergenerational transmission of difficult life course transitions like marital dissolution or divorce. Some members of program for example are also young parents and some of them are already divorced. They have similar problems as their parents and grandparents. In particular, studies have found that parental divorce increases the likelihood that adult children will experience separation or divorce (Glenn and Kramer 1987; Keith and Finlay 1988; Amato 1996; Demšar Pečak, 2014).

It is very important that interventions are held in collaboration with various institutions because in that way the assistance is more effective and especially prolonged. For the successful achievements of program mentors need the support of various external institutions and individuals. It is very important that they are all involved in the program as professional team: advisors at the Employment Service, representatives of police, advisers for social work, counsellors in schools and mentors in the workplace, doctors, therapists and others who are closely linked to the individual participants. Thus, the entire team helps participants to the achievement of a career plan. As already mentioned cooperation of the relational therapist is also important for the quality achievement of the individual career goal. The majority of program participants have symptomatic deep-rooted patterns of interpersonal interactions. Therapeutic work with individuals may lead to the gradual change of inappropriate models of interpersonal interactions and thereby the change of the individual's mental structure and regulation of psychobiological conditions (Demšar Pečak and Ovsenik, 2014; Demšar Pečak 2017). 
Gostečnik (2010, 2011) states that individual fundamental relations, and related basic affects, such as fear, anger, horror, shame, contempt, disappointment as well as emotional calmness and satisfaction learn in the family. These relations are marked forever, because they are internalized in childhood based on mechanism of projection-introjection identification and consolidated based on compulsive repetition. Even Cvetek (2009) mentions that children get the basic patterns, rules for behaviour, emotions the basics of the language and culture skills of expression and thinking in the family.

Various authors (Haley, 1987; Minuchin, 1981; Framo, 1992; Boszoromenyi-Nagy, 1986 and Bowen, 1978, in Gostečnik, 2008, 2010, 2011) focused on covert pathological transactions and many times unsolved transfers of painful mental content to a particular individual who has unconsciously adopted this contents. Because of this internalization, he or she becomes identified patient or "scapegoat" of a certain family. The identified patient is therefore an individual who carries and maintains symptomatic patterns of relationships within the family through the mechanism of compulsive repetition that is forced repetition of basic patterns of interpersonal interactions. Framo mentions (i.e.: Gostečnik 2011 p. 180), that certain patterns or family topics skip a whole generation, and then mysteriously settle again in the new generation, who do not even know where these painful contents come from. Framo (i.e.: Gostečnik 2011, p. 180) also states how the past can affect the present and how "family through several generations develops dysfunctional patterns of behaviour, feeling, beliefs and above all interpersonal interactions."

Therapeutic approach is in the program PUM-O is very important, because in most of the participants' families' intergenerational transmission can be found. With the majority of the participants, their relational needs are not satisfied, so this deficit is reflected in loneliness, dissatisfaction, fear, despair, self-injuring, aimless vegetating, violence, depression and various addictions (Žvelc, 2016). The acquired patterns can be changed and improved with the professional therapeutic help. Therefore, the therapist also works with the individuals as well as the entire group. The therapist uses compassionate approach and addresses inadequate forms of participant's behaviour models. When we talk about changing the depth patterns of behaviour, emotions and beliefs we primarily focus on the patterns of the family model from childhood (the relationship mother-child). The further emotional, cognitive and inter-relational experience of thinking and response largely depends on the primary relationship (Gostečnik, 1997, 2007).

With emphatic therapeutic approach and modification of depth patterns of behaviour, emotions and beliefs the participants may respond differently to other co-participants. They also begin to experience and respond differently to the relationships in the home environment. In this way the entire system of interpersonal interaction among participants, as well as the system of interaction between the members of their family can change. The aim of the therapeutic approach is to help the participants find the new functional patterns of behav- 
iour, emotions and beliefs. That could solve problems which are a result of relationships that occur and transmit from generation to generation. The most of the participants have often regulated psychobiological condition through nonfunctional forms of behaviour and emotion (e.g. inappropriate communication, violence, self-injuring, various addictions, obsessive-compulsive disorder, suppression of emotions, depression, disinterest).

In the evaluation (Možina et al., 2010), it was found out that the participants wish to have more common leisure activities (excursions, holidays, field trips, afternoon activities), extension programs in the afternoons and psychotherapeutic help, also to their parents. In the program they have the feeling of security and belonging, but it can also satisfy their relational needs, which until now they have not been able to satisfy.

In achieving career goals of the participants an emphatic therapeutic approach is very important because the individuals must first resolve all symptomatic deep-rooted patterns of interpersonal interaction and thereby strengthen appropriate and functional regulation of painful and destructive affects. Surpassing old rooted patterns means consciously build new relationships that will include all of those needs, desires, and feelings the participants in the domestic environment from significant others were not given because those were not able to or didn't want to identify them.

On the therapy the participant can exceed the old patterns of behaviour, emotions and beliefs and as mentioned by Gostečnik (2007, p. 280), the therapy is interactive space in which the therapist must play the role of "good enough mother" and establish a "safe space" in which the individual can be able to live again.

\section{Conclusions}

Based on new pledged foundations of psychic structure and regulation of inadequate psychobiological condition, the participants can follow their education or employment goals. The old clamps based on the mechanism of projection-introjection identification and consequent compulsive repetition does not force them any longer to a vicious circle of non-functional interpersonal interactions. To achieve its objectives, mentors need support of a variety of professionals. Because the program is not a therapeutic one and the mentors generally are not therapists, it is extremely important that the mentors in the program, unless they are also therapists, include other relational therapists.

For many participants the program is the only way out of the current hardship and the only possibility of reactivation in everyday life. Many participants in the program PUM-O for the first time experience safe, compassionate, predictable and respectful relations. Thus, the participation in the program serves as a safe place, where the participants receive basic security, feeling of understanding, acceptance and value. The participation in program is also a quality platform for further career. 


\section{References}

AINSWORTH, M. D., BLEHAR, Mc., WATERS, E., WALL, S. (1987). Patterns of attachment: A psychological study of the strange situation. NY: Erlbaum Associates Pub.

AMATO, P. R. (1996). Explaining the Intergenerational Transmission of Divorce. Journal of Marriage and the Family 58: 628-641.

CAPALDI, D., PEARS, K., PATTERSON, G., OWEN, L. (2003). Continuity of parenting practices across generations in an at-risk sample: A prospective comparison of direct and mediated associations. Journal of Abnormal Child Psychology, 31, 127-142.

CHEN, Z., KAPLAN, H. (2001). The intergenerational transmission of constructive parenting. Journal of Marriage and the Family, 63, 17-31.

CVETEK, R. (2009). Bolečina preteklosti: Travma, medosebni odnosi, družina, terapija. Celje: Društvo Mohorjeva družba.

DEMŠAR PEČAK, N. (2014). Model socialnega marketinga pri reševanju problemov $v$ partnerskem odnosu: doktorska disertacija. Novo mesto

DEMŠAR PEČAK, N., Ovsenik M. (2014). Social Marketing and Intergenerational Dialogue, - A New Research Approach to Resolve Problems in Partner Relationships. Media, culture and public relations 5(2), 147-160

DEMŠAR PEČAK, N. (2017). Nujnost in pomen terapevtskega pristopa pri izvajanju programa »Projektno učenje mlajših odraslih (PUM-O). Medsebojni odnosi in spremembe v terapiji.VII. kongres zakonskih in družinskih terapevtov Slovenije 2016. Teološka fakulteta Ljubljana

GLENN, N. D., KRAMER, K. B. (1987). The Marriages and Divorces of the Children of Divorce. Journal of Marriage and the Family 49: 811-825.

GOSTEČNIK, CH. (1997). Človek v začaranem krogu. Ljubljana: Brat Frančišek in Frančiškanski družinski center.

GOSTEČNIK, CH. (2007). Relacijska zakonska terapija. Ljubljana: Brat Frančišek in Frančiškanski družinski center.

GOSTEČNIK, CH. (2008). Relacijska paradigma in travma. Ljubljana: Brat Frančišek in Frančiškanski družinski center.

GOSTEČNIK, CH. (2010). Sistemske terapije in praksa. Ljubljana: Brat Frančišek in Frančiškanski družinski center.

GOSTEČNIK, CH. (2011). Inovativna relacijska družinska terapija. Ljubljana: Brat Frančišek in Frančiškanski družinski center.

ISTENIČ, S.A. (2003). Evalvacija socialno integracijske vloge programa Projektno učenje za mlajše odrasle. Filozofska fakulteta v Ljubljani. Ljubljana.

KEITH, V. M., FINLAY, B. (1988). The Impact of Parental Divorce on Children's Educational Attainment, Marital Timing, and Likelihood of Divorce. Journal of Marriage and the Family 50: 797-809. 
MARTIN-MATTHEWS, A., KOBAYASHI, K. (2009). Intergenerational Transmission - Cultural Transmission: Values, Norms, And Beliefs, Retrieved. http://family.jrank.org/pages/917/Intergenerational-Transmission.htm

MOŽINA, E., JAVRH, P., KURAN M., VRBAJNŠČAK, K., ŠMALCELJ, P., RADOVAN, M., JAMŠEK D., (2010). Evalvacijska študija. Javno veljavni program Projektno učenje za mlajše odrasle (PUM). Program Temeljno usposabljanje za mentorje (TUM PUM). Andragoški center Slovenije. Ljubljana

SERBIN, L., KARP, J. (2003). Intergenerational studies of parenting and the transfer of risk from parent to child. Current Directions in Psychological Science, 12, 138-142.

ŽALEC, N. (2015). Program Projektno učenje mlajših odraslih PUM-O. Andragoški center Slovenije. Ljubljana

ŽVELC, G. (2016). Relacijske potrebe, uglaševanje in prisotnost v psihoterapiji. Medsebojni odnosi in spremembe v terapiji. VII. kongres zakonskih in družinskih terapevtov Slovenije 2016. Teološka fakulteta Ljubljana: 5 